Wittgenstein Reading, edited by Sascha Bru, Wolfgang Huemer, and Daniel Steuer (De Gruyter, 2013), 39-53.

\section{William Day}

\section{To Not Understand, but Not Misunderstand: Wittgenstein on Shakespeare}

The reason I cannot understand Shakespeare is that I want to find symmetry in all this asymmetry. It seems to me as though his pieces are, as it were, enormous sketches, not paintings; as though they were dashed off by someone who could permit himself anything, so to speak. And I understand how someone may admire this \& call it supreme art, but I don't like it. - So I can understand someone who stands before those pieces speechless; but someone who admires him as one admires Beethoven, say seems to me to misunderstand Shakespeare.

(VB 1998, p. 98a-bi)

\section{1.}

The entire corpus of Wittgenstein on Shakespeare, located mostly across two stretches of the remarks collected under the title Vermischte Bemerkungen (Culture and Value), amounts to no more than a handful of pages. One is thus able to read everything Wittgenstein wrote on Shakespeare in about five minutes. Even so, and even though this is Wittgenstein, I will begin by condensing his remarks. That what Wittgenstein says about Shakespeare can be condensed, summarized, is perhaps the first remarkable fact about his writings on Shakespeare. Think of how very little of the later writings of Wittgenstein - notably his Philosophical Investigations - yields itself to condensation or summary. It suggests that these remarks, besides being mildly repetitious, are drawn out of him somehow differently from the remarks in the Investigations. They represent an engagement with language (specifically with Shakespeare's language) that calls for a response different in kind from his interlocutory windings through philosophical temptations and their diagnoses that are the work of the Investigations. If anything in Wittgenstein's corpus prepares us for this.sort of engagement with someone else's words, it would be his remarks on Frazer's The Golden Bough, or on Freud, or some of the late remarks in Part II of the Investigations from roughly the same period as the bulk of his remarks on Shakespeare (that is, after 1945). But I find that even

1 Referentes to remarks in $V B$ are given by page number followed hy a letter indicating the position of the remark on that page" for example, "98a" for the first remark on paige 98, "981, for the second remark, ete. 
these stretches of Wittgenstein's prose are not nearly as easy to summarize as what he has to say about Shakespeare's writing.

Consider, then, the following one-paragraph condensation of Wittgenstein on Shakespeare, which I cast in the first person:

"Shakespeare is overpraised. He may deserve high praise, but much of the praise he receives is made without understanding and for the wrong reasons ( $V B$ 1998, p. 55b, 95h, 98b). What one can say is that Shakespeare is not like any other poet (VB 1998, p. 95f, 95h, 96c). But this singularity is a two-edged sword. On the one hand: he is akin to a natural phenomenon, singing as the birds sing - that is, a creator of language, of new natural linguistic forms in the face of which one is left only to stare in wonder, speechless (VB 1998, p. 56d-e, 89b, 95f, 95g, 96b, 96c, $96 \mathrm{f}, 98 \mathrm{a}-\mathrm{b})$. That is why his greatness is displayed only in the whole corpus of his plays; what justifies him is the style of his whole work, whose ease and authority one just has to accept if one is to admire him properly (VB 1998, p. 56d-e, 89b). On the other hand: because he is like a creator of language with a law of his own, he is not naturalistic, is in fact completely unrealistic, his language and world like the language and world of a dream (VB 1998, p. 42f, 89b, 96a). That doesn't mean that his characters are not worth looking at; but they're not true to life (VB 1998, p. 96a). Hence to say that Shakespeare stands by himself means that he does not stand by or for us - at least, he could not regard himself as a prophet or teacher of mankind, would not be able to reflect even on 'the lot of the poet', cannot be said to have a 'great heart' (as one might say of Beethoven), and doesn't leave us feeling that we have come into contact with a great human being (VB 1998, p. 96b, 96e, 96f). Rather, his greatness is such that he can permit himself anything; his works are not the product of a struggle but more like something dashed off, like enormous sketches rather than paintings. Call it supreme art if you wish, but ich mag es nicht - I don't like it (VB 1998, p. 98a)."

I want this summary of Wittgenstein's remarks on Shakespeare to accomplish two things. First, it should help us recover or recognize, if only for a moment, the full force of their outrageousness, which one risks losing sight of the more time one spends with them. Reading across the published discussions of Wittgenstein's remarks on Shakespeare since Culture and Value appeared over three decades ago, one senses an interest to explain away or otherwise soften the impact of their brashness. I do not say that Wittgenstein's remarks are indefensible as a thesis - say especially the thesis that what is most singular in Shakespeare's language, what Western culture loves most about Shakespeare in its centuries-long embrace of him, is what is most unlovable about him. But Wittgenstein's remarks are not part of a thesis. He does not do more with them, and their aim is not to present a conclusion of criticism but to articulate a feeling or intuition. The most obvious evidence for this is that nowhere in his published notebooks does Wittgenstein quote a passage from one of the plays or so much as make reference to a particular play or sonnet - a sort of stark and perverse instantiation of his insistence that Shakespeare's greatness could lie only in the entire achievement. ${ }^{2}$ This brings us to the second thing I want my summary to suggest or prepare. To understand Wittgenstein's remarks it is not sufficient to hold them up to Shakespeare (however revelatory of his achievement they prove to be) or to Wittgenstein (however inspired by his vision of language they prove to be). What one must do is find how they hold up on their own, or what holds them up. That is, one must ask - and undoubtedly one wants to know - what the uneasiness they express over Shakespeare betokens. It may be an uneasiness with which we're not entirely unfamiliar; on the contrary, we who read Shakespeare may be like blind men grabbling in a room where Wittgenstein alone has his hands on the jaws of the beast. My guiding thought is that Wittgenstein's misgivings about Shakespeare spring not from a philosophical disagreement with him - let alone from a sense that Shakespeare lacks philosophical weight - but from a difference in philosophical temperament, the nature of which marks two distinct options in one's response to the threat of skepticism and to the naturalness and inevitability of tragedy.

\section{2.}

George Steiner's 1986 lecture “A Reading against Shakespeare” - still one of the longest consecutive discussions of Wittgenstein's remarks on Shakespeare - is not shy in acknowledging the apparent craziness of Wittgenstein's assertions. The claim that Shakespeare stands alone is said to be "surely ... exaggerated in a manner characteristically Germanic” (Steiner 1996, p. 119). Wittgenstein's denial that Shakespeare is true to life is "very difficult to place, let alone take seriously" (Steiner 1996, p. 120). Yet, and to his credit, Steiner goes on to take these remarks seriously in the very sense he says it is difficult to do. Steiner argues that Wittgenstein perceives an absence of the religious and explicitly ethical in Shakespeare that he located more easily not only in obvious places like Dante and Tolstoy (and, one should add, Dickens) but also in Goethe, Kafka, and Thomas Mann. The crux of Steiner's argument takes off from Wittgenstein's question, "Was he [Shakespeare] perhaps a creator of language rather than a poet?”(VB 1998, p. 95f).

2 The absence, in Wittgenstein's remarks, of a thesis about Shakespeare or of passages quoted from his plays has been observed most recently by Wolfgang Huemer (2012). 
Steiner underscores the distinction between a Sprachschöpfer - a wordsmith or a crafter of words, even one such as Shakespeare who, as Steiner puts it, "has made the world at home in the word" (Steiner 1996, p. 123) - and the Dichter or true poet, whose talent is not a knowingness or craft-knowledge, but an ethical insight or willingness to bear witness, a compassion for others expressed as a desire to save them from emptiness and death, the communication (as in Heidegger) of the mystery of being. It is, for Steiner, this German aesthetic understanding of the Dichter's calling that is at work in Wittgenstein's remark, and Steiner thinks Wittgenstein is on to something when he withholds from Shakespeare this higher appellation. Similarly, Peter Hughes, in an essay published two years later, reads this same remark as faulting Shakespeare for his assault on philosophy - not (negatively) for his lacking the ethical insight of a Dichter but (positively) for his ease at language creation. Shakespeare's singular way with words threatens philosophy by undermining the necessary commonality of language, by forcing words to turn on something private or personal, and so to turn in ways Wittgenstein explicitly warns philosophy against in certain well-known sections of the Investigations (Hughes 1988, p. 381). For both Steiner and Hughes, then, Wittgenstein's critique of Shakespeare acknowledges that Shakespeare can do with the English language virtually anything he pleases, while at the same time it raises a question about the worth of this skill or freedom. For Hughes, the question is: Is doing whatever you please with language desirable? For Steiner, the question is: Is doing whatever you please with language enough? - a question Steiner seems to welcome from philosophy in the name of Shakespearean criticism.

I don't doubt that the question "Is linguistic mastery enough?" can prove fruitful for readers of Shakespeare. But I don't think Wittgenstein is raising either question, for two reasons: I think he denies of Shakespeare a not unimportant component of linguistic mastery, and I think he does not deny of Shakespeare a certain philosophical or ethical seriousness (though he may not explicitly confirm it, either). Let us take these in turn.

A key element of Wittgenstein's critique of Shakespeare appears at the beginning of a remark from 1946. He says that "Shakespeare's similes are, in the ordinary sense, bad" (VB 1998, p. 56d; emphasis in original). Hughes passes over the remark entirely, and while Steiner quotes much of it he is silent about this first sentence. Perhaps it is too straightforward a criticism for a literary critic. But in point of fact it is the only sentence in his notebooks where Wittgenstein specifically refers to the language that Shakespeare “creates.” (I don't mean that similes, metaphors, and the like are the only sort of linguistic creation that Wittgenstein has in mind in calling Shakespeare “a creator of language.” Surely the Dichter creates these, too, and surely Wittgenstein has in mind the world-cre- ating power of a Hamlet or Macbeth no less than the specific rhetorical figures they employ. But it seems silly to imagine, as Hughes seems to imagine, that by calling Shakespeare "a creator of language" Wittgenstein is accusing him of creating, if not a private language, then "a unique and alien world" populated by people "whose outer reveals no inner" (Hughes 1988, p. 381) - especially since, as Hughes knows, Wittgenstein creates such worlds himself, a fact to which I return below.) Why does Wittgenstein single out Shakespeare's use of similes, and what makes them bad "in the ordinary sense," so that they could only be good if one takes them in some extraordinary sense - that is, as part of a singular language? ${ }^{3}$

Here it is important to recognize something of Wittgenstein's own powers of language, in particular his remarkable talent for similes and, more broadly, figures of comparison - by which I mean to include everything from analogies to what Wittgenstein called, in characterizing his philosophical method, the invention of "intermediate cases," instances of which direct us towards "that understanding which consists in 'seeing connexions'," itself the goal of what he meant by a "perspicuous representation" or "overview" (Übersichtlichkeit) (PI 1958, §122). Given the importance of figures of comparison to Wittgenstein’s way of doing philosophy, it shouldn't surprise that he was good at it, and knew that he was good at it, referring to himself half-deprecatingly but still seriously as a crafter of beautiful similes (Monk 1990, p. 363). Here is one example, drawn from a remark he thought to include in the Foreword to the Investigations: "Only every so often does one of the sentences I am writing here make a step forward; the rest are like the snipping of the barber's scissors, which he has to keep in motion so as to be able to make a cut with them at the right moment" (VB 1998, p. 76a). Compare this striking image - revelatory both of its author and of the process of writing, so often felt as a movement without forward motion - to a metaphor from Richard II that Wittgenstein once mentioned in conversation, and a likely instance of the sort of "bad" Shakespearean figure he had in mind (Monk 1990, p. 568). Mowbray there says, "Within my mouth you have engaol'd my tongue / Doubly portcullis'd with my teeth and lips” (Shakespeare 1876, 1.3.166-167). ${ }^{4}$

3 Jonathan Pugh argues that what Wittgenstein found "bad" (yet interesting) in Shakespeare's similes was their employment of "metaphysical wit," a way of writing "characterized by extreme and extended juxtapositions of unnaturally coupled similes" (Pugh 2012, p. 238-239). While Pugh's thesis is instructive, it proceeds without the support of a single Shakespearean turn of phrase that Wittgenstein actually critiques. Nor does Pugh consider that Wittgenstein's criticism of Shakespeare's similes is born from Wittgenstein's own experience with and talent for making similes. I correct both of these faults in the reading presented here.

4 References are to act, scene, and line. 
No doubt the figurative possibilities of a portcullis, the iron or wooden gate to a castle that can be raised and lowered, appeared more naturally to an Elizabethan poet than it does to us. But that seems to be no part of Wittgenstein's critique. (And his choice of example ought to lead us to dismiss the suggestion, made by Steiner (Steiner 1996, p. 117) and indirectly by F. R. Leavis (Leavis 1984, p. 59), that Wittgenstein's difficulty with Shakespeare stems from the antiquity of Shakespeare's English and the non-standardness or non-nativeness of Wittgenstein's English. If one is tempted by this hypothesis, one should remember that the authority Wittgenstein acknowledges as reminding him of the greatness of Shakespeare is, after all, Milton, and that Wittgenstein's sense of Milton's English is adequate enough that he can say, "I take it for granted that he [Milton] was incorruptible" (VB 1998, p. 55b).) What does seem part of Wittgenstein's critique of Shakespeare's figures is the obviousness of such an image as the teeth and lips as a gate for the tongue, even when one acknowledges that here it is closed to keep something in rather than to keep something out.

What should one conclude from the comparison of this metaphor to Wittgenstein's simile of the barber's scissors? I don't claim that Wittgenstein's figure is plainly better, nor am I suggesting that as familiar a Shakespearean alternative as “Juliet is the sun" couldn't compete with it. It is enough for my present purpose if we can agree that, in this instance at least, Wittgenstein could hold his own with Shakespeare. One might even consider whether Shakespeare's portcullis'd tongue is as striking as the similative tongue in the following, from Wittgenstein's so-called Big Typescript: "The philosopher strives to find the liberating word, and that is the word that finally permits us to grasp what until then had constantly and intangibly weighed on our consciousness. (It's like having a hair on one's tongue; one feels it, but can't get hold of it, and therefore can't get rid of it.)" (BT 2005, p. 302). But the point I mean to make plausible is that, when Wittgenstein speaks of Shakespeare's singularity and raises the possibility that he was a creator of language who could say of himself "I sing as the birds sing," Wittgenstein is not asserting the admiring commonplace that Shakespeare's writing exhibits his linguistic mastery. Wittgenstein does not misunderstand Shakespeare. He does not mistake Shakespeare for a mere wordsmith and then fault him for not being more than that, as Steiner and Peter B. Lewis would have it (Lewis 2005, p. 251). When Wittgenstein raises the possibility (he does not assert it, as Steiner all but assumes) that Shakespeare is a Sprachschöpfer, a language-maker, he sees himself as speaking neither from understanding nor from misunderstanding, but from that particular poverty of one who wants to articulate the cause of an absence in himself, specifically the absence of a (or the right) critical response to a body of work generally praised as the best of its kind. To that extent his uneasiness is familiar enough; it is the only honest response to something whose importance we acknowledge but whose greatness we find we do not and cannot "get." (There may be countless ways to appreciate something and countless ways to despise it, but there seems to be only one way to not get it.) And I will add, in anticipation of the next section, that Wittgenstein's remarks on Shakespeare's way with words are compatible with my earlier suggestion that his uneasiness springs from a difference in philosophical temperament, here expressed as an anxiety or fear that the language of Shakespeare's plays stirs up in him.

\section{3.}

Perhaps the best evidence that Wittgenstein's remarks on Shakespeare are guided by an anxiety or fear engendered by Shakespeare's writing occurs in a pair of consecutive remarks about the dream-work and dreams from Wittgenstein's 1949 notebooks. In the later of the two remarks, Wittgenstein explicitly identifies the field of Shakespeare's impressiveness with the field of dreams. Both can seem "all wrong," even "absurd," and yet also impress us as "completely right" (VB 1998, p. 89b). In the earlier remark, where Wittgenstein speaks only of dreams (that is, just before the connection to Shakespeare occurs to him, or is called up from him), the question of the cause of our recollections of dreams, with their peculiar patchwork quality, gets raised (VB 1998, p. 88h-89a). And while, here as elsewhere, Wittgenstein is intent to show that the demand for causes may be misplaced, a demand for the wrong thing, he entertains Freud's answer long enough to supplement it with his own. He agrees, following Freud, that our thoughts associated with dreams may relate to our daily life and to our wishes, but he adds his belief that they can relate to our fears as well. If one follows this suggestion, as one can imagine Wittgenstein found himself doing in his subsequent remark, how should one further specify the recollections or associations that Shakespeare's plays engender in him? Does it matter whether they arise from daily life (which Wittgenstein denies: "things aren't like that" (VB 1998, p. 89b)), or from wishes, or from fears? But that amounts to asking, what stands in the way of Wittgenstein's understanding Shakespeare? (We have said his problem is not one of misunderstanding - that is, it's not a matter of seeing the wrong Shakespeare.)

In a remark from 1946 - concluding his disparaging of Shakespeare's similes - Wittgenstein suggests a possible answer to himself: "That I do not understand him [Shakespeare] could then be explained by the fact that I cannot read him with ease. Not, that is, as one views a splendid piece of scenery" (VB 
1998 , p. 56e). The concept of an inability to read easily, as in seeing the splendidness of a splendid scene, is related to the general concept that occupies Wittgenstein throughout his later career - the concept of seeing an aspect - and that receives its most concentrated exposition in the pages of Part II, section 11 of the Investigations. ${ }^{5}$ The emblem, not to say the icon, of these pages is the figure known as Jastrow's duck-rabbit, a line drawing that is intentionally ambiguous between being that of a duck and that of a rabbit (PI 1958, p. 194b); and a feature of this figure that Wittgenstein highlights is the ease with which we can effect the gestalt-switch from one to the other. This easy ability is generalized, or I might rather say particularized, over dozens of similar but distinct examples, including, among others, our relation to schematic drawings (PI 1958, p. 193f, 200c, 203a), to puzzle-pictures (PI 1958, p. 196b, 199b), to full-fledged pictures (PI 1958, p. 201e, 202e, 203b), to everyday objects ( $P I 1958$, p. 206e), to musical tempi and aesthetic experience broadly conceived (PI 1958, p. 202h, 206i), to words (PI 1958, p. 202g, 214d ff.), and (by implication but also explicitly) to other people (PI 1958, p.193a, $197 \mathrm{~g}$ ). Wittgenstein does not imagine, of course, that we all share an ease in effecting a change in aspect in all of these cases. He says, in speaking of the more complicated instances of aspect-seeing: “'Now he's seeing it like this', 'now like that' would only be said of someone capable of making certain applications of the figure quite freely" (PI 1958, p. 208d). To someone incapable, for whatever reason, of exercising this freedom or ease in reading the aspects of the world, Wittgenstein gives the name "aspect-blind." And a characteristic of the aspectblind is the inability to see how something (a figure, an object, a stretch of music) invites the seeing (or hearing) of different aspects (PI 1958, p. 213f-214a).

If one reads Wittgenstein's remark about his inability to read Shakespeare "with ease," "as one views a splendid piece of scenery," in light of his contemporaneous invention of and interest in the concepts of aspect-seeing and aspectblindness, one is likely to notice that Wittgenstein is describing his difficulty with Shakespeare's words in the language of a condition, albeit an ambiguous one (aspect-blindness) ${ }^{6}$, rather than describing it as a temporary aesthetic difficulty. These are - particularly in Wittgenstein's thinking - two distinct and separate options. Were it an aesthetic difficulty, it would find its solution the way any

5 References to remarks in Part II are given by page number followed by a letter indicating the position of the remark on that page - for example, "193a" for the first remark on page 193 "193b" for the second remark, etc.

6 As I argue elsewhere (Day 2010, p. 206), Wittgenstein intends us to notice our ambivalent reaction to the possibility of aspect-blindness: it is a condition we can neither fully imagine nor fail to find familiar. temporary failure to aspect-see, or to see the point of something, does. Here is Wittgenstein noting the difference between his failing and then coming to see pictures or hear music that once puzzled him:

I could say of one of Picasso's pictures that I don't see it as human. Or of many another picture that for a long time I wasn't able to see what it was representing, but now I do. Isn't this similar to: for a long time I couldn't hear this as of a piece, but now I hear it that way. Before it sounded like so many little bits, which were always stopping short - now I hear it as an organic whole. (Bruckner.) (LW 1982, §677)

One might come to see the human in one of Picasso's pictures, for example, by letting one's eye roam "so that you no longer see it as one picture, in the normal sense of the word, but as several pictures, each of which has its own application" (LW 1982, §805).

But Wittgenstein imagines his difficulty with Shakespeare's words differently. He imagines it as akin to the difficulty he mentions late in the aspect-seeing section of the Investigations, where he notes the "important" fact that "one human being can be a complete enigma to another" (PI 1958, p. 223f). Or think of his difficulty with the splendid landscape of Shakespeare's prose by contrasting that difficulty with our ordinary relation to a picture of a landscape: "I might get an important message to someone by sending him the picture of a landscape. Does he read it like a blueprint? That is, does he decipher it? [No.] He looks at it and acts accordingly. He sees rocks, trees, a house, etc. in it” (RPP 1980b, §447). To read a picture like a blueprint (cf. PI 1958, p. 204i) would be, at best, to merely know what it is about without seeing it. That seems to be how Wittgenstein understands his condition as a reader of Shakespeare, unable to "accept him as he is in the way you accept nature, a piece of scenery e.g.” (VB 1998, p. 56d). While Wittgenstein professes aversion to other writers and composers, his most concentrated articulation of a failure to understand another's writing is reserved for Shakespeare.

And yet, by describing his relation to Shakespeare's words in terms reminiscent of a condition he invents, his "fictitious natural history" (PI 1958, p. 230a) of aspect-blindness, Wittgenstein is being disingenuous. Casting himself as suffering from a condition (an inability to read with ease, a blindness), he avoids coming to terms with what lies behind his "condition" (something he sees, an aspect of Shakespeare's words that is blocking understanding). Wittgenstein says "I do not understand him [Shakespeare]" - a self-description that, as noted above, he associates with dream-like recollections of an indeterminate cause not because he suffers from a condition of blindness but because he is seeing an aspect of Shakespeare's words that hides or camouflages them, as the duck-aspect of the duck-rabbit hides the rabbit-aspect. 
There is a strong and serious candidate for what lies behind Wittgenstein's singular uneasiness over Shakespeare. Coming to see it depends upon recognizing that both Wittgenstein and Shakespeare can be read as responding to the human threat of skepticism, just as Descartes can be read as skirting or cheating that threat. The argument for Shakespeare is made in Stanley Cavell's readings of (most famously) Lear's avoidance of Cordelia's love, Othello's doubt of Desdemona's transparent faithfulness, and Leontes' male suspicions about whether and what he has fathered. ${ }^{7}$ These readings are offered alongside Cavell's understanding of the Investigations as Wittgenstein's diagnosis and treatment of modernity's obsession to turn our relation to the world and to others into matters of knowing, and so into matters of doubt. Here is how Cavell sets up the trials of skepticism in his reading of Othello:

[In Othello] we have the logic, the emotion, and the scene of skepticism epitomized. The logic: 'My life upon her faith' (I, iii, 294) and '... when I love thee not / Chaos is come again' (III, iii, 91-92) set up the stake necessary to best cases; the sense I expressed by the imaginary major premiss, 'If I know anything, I know this'.... The emotion: Here I mean not Othello's emotion toward Desdemona, call it jealousy; but the structure of his emotion as he is hauled back and forth across the keel of his love. Othello's enactment, or sufferance, of that torture is the most extraordinary representation known to me of the 'astonishment' in skeptical doubt. ... The scene: Here I have in mind the pervasive air of the language and the action of this play as one in which Othello's mind continuously outstrips reality, dissolves it in trance or dream or in the beauty or ugliness of his incantatory imagination; in which he visualizes possibilities that reason, unaided, cannot rule out. (Cavell 1979, p. 483-484)

In this same close reading of Othello Cavell provides the following, more general enunciation of tragedy's revelation of skepticism:

But then this is what I have throughout kept arriving at as the cause of skepticism - the attempt to convert the human condition, the condition of humanity, into an intellectual difficulty, a riddle. ... Tragedy is the place we are not allowed to escape the consequences, or price, of this cover. (Cavell 1979, p. 493)

Wittgenstein's interest throughout the Investigations in skepticism, though widely recognized because of his repeated questioning of "what we go on" in carrying out a task (for example, in continuing a series of numbers), is often misread as his attempt to refute skepticism. But a Wittgensteinian criterion

7 For King Lear, see Cavell 1969, p. 267-353. For Othello, see Cavell 1979, p. 481-496; a version of these pages appears in Cavell 1987a, p. 125-142. For The Winter's Tale, see Cavell 1987b, p. $193-221$. does not negate the concluding thesis of skepticism, that we do not know with certainty of the existence of the external world (or of other minds). On the contrary, Wittgenstein, as I read him, rather affirms that thesis, or rather takes it as undeniable, and so shifts its weight. What the thesis now means is something like: Our relation to the world as a whole, or to others in general, is not one of knowing, where knowing construes itself as being certain. (Cavell 1979, p. 45)

If one grants the connections, no more than sketched here, between Shakespeare and Wittgenstein - not only that both treat the human impulse toward skepticism thematically (each in his way) but that both diagnose skepticism as the attempt to interpret "a metaphysical finitude as an intellectual lack" (Cavell 1979, p. 493) - the wonder becomes how Wittgenstein could have failed to see in Shakespeare's tragedies, as he saw in Augustine's Confessions, a working out of his own most pressing concerns (however different in form from his own writing). ${ }^{8}$ But we need not imagine that he missed it; not completely. In truth, no serious reader can miss Shakespeare's interest in the practical consequences of skepticism (our failure to acknowledge others) except insofar as one can miss the obvious (cf. Cavell 1969, p. 310). But that is not to say the obvious isn't easy to miss. What we can say is this: to miss the extent to which our failed relations with others mirror philosophy's skepticism of the existence of others, and that Shakespearean tragedy trades in the extreme consequences of these failed relations, would be to simply misunderstand Shakespeare. Such a reader would be left to praise Shakespeare for all the wrong reasons (for example, for his linguistic mastery). Wittgenstein is not such a reader. Rather than missing Shakespeare's shared concerns completely, Wittgenstein is merely covering his ears to the sound of them, or to the way Shakespeare gives voice (voices) to them. ${ }^{9}$

8 For a superb account of what Wittgenstein saw in Augustine, see Steven Affeldt's essay in this volume.

9 Even if it is only in some sense that Wittgenstein is not missing these shared concerns, that would be enough to counter George Steiner's claim that Wittgenstein sees Shakespeare as lacking ethical seriousness, and also Peter Hughes's claim that Shakespeare and Wittgenstein operate from conflicting notions of philosophical seriousness. 
4.

For fear of what, or in anxiety over what, does Wittgenstein cover his ears? Consider once more the charges leveled by Wittgenstein against Shakespeare's language: its unnaturalness; its being a law to itself (and so appearing as lawlessness); its dream-like strangeness yet also its dream-like coherence; the characterizations of its createdness as something primal or prehuman, only in that sense natural; and especially, its disturbing asymmetry and spontaneity, the sense that Shakespeare's next words are not controlled by the words that preceded them, that anything is permitted. This is a picture of the natural world, and of our relation to it, as seen from the side of chaos, or in which chaos and madness threaten to break out at any moment (as they eventually do in Hamlet, in King Lear, in Othello, and even in the late-Shakespeare romance The Winter's Tale). ${ }^{10}$ If it is right to say that Wittgenstein does not miss the skeptical problematic running through Shakespeare, then what he closes his ears to, the cause of his running from Shakespeare, is the sound of the raw motives to skepticism, and of language gone wild, absent their philosophical elaborations and filigrees - the latter being expressions of skepticism that help to preserve Wittgenstein even as he does battle with them.

Earlier I had occasion to note Wittgenstein's remarking that "one human being can be a complete enigma to another" (PI 1958, p. 223f). But in that section of the Investigations his expressions of mystification ("We do not understand the people"; "We cannot find our feet with them") are meant, understandably, to counter a false impression: the impression that his success at dissolving the picture of "the inner" - the picture that what another is thinking and feeling is hidden from us - has equally defeated the fact of our metaphysical separateness. Wittgenstein does not feel that it has, or should, and a more nuanced view of how matters stand appears in the subsequent remark: "I cannot know what is going on in him' is above all a picture. It is the convincing expression of a conviction. It does not give the reasons for the conviction. They are not readily accessible" (PI

10 A criticism of this reading might be that I keep referring, unremittingly if not exclusively, to Shakespeare's tragedies, not to "the whole corpus of his plays" (VB 1998, p. 89b). But that criticism misreads Wittgenstein's appeal to "the whole corpus" as an appeal to something he understands and is theorizing about, when what he says is that he does not understand the whole corpus, but that it must be what those who find Shakespeare great are referring to. That Wittgenstein is thinking, unremittingly if not exclusively, about Shakespeare's tragedies is what my reading provides evidence for if it is convincing. At the least, we know Wittgenstein is not not thinking about the tragedies, given the anecdotes of his seeing, discussing, and even borrowing a motto from King Lear (Rhees 1984, p. 73, 118, 157).
1958, p. 223g). Wittgenstein is not here dismissing as simply false what this picture expresses - as if I could know what is going on in him if I just looked again, or the right way, or allowed the other to state more fully how things are with him. Perhaps if I or he were to make these efforts I would indeed find my feet with him; but that is not guaranteed. What I wish to underscore is that it is not part of Wittgenstein's understanding of grammar, or the systematization of language, that my failure to find my feet with him can in all cases be overcome by some further philosophical therapy. Wittgenstein seems to assert, on the contrary, that on some occasions, the enigma of others is perpetual and unending.

But it is not, so far, tragic. While these later pages of Part II of the Investigations give expression to a natural and irreparable schism between (some) human others, no one is responsible for this schism. (That is all my use of "natural" here is meant to convey.) To get closer to tragedy and the tragic expression of skepticism in the later Wittgenstein, one needs to turn to a late manuscript remark - one of the last collected in Culture and Value - that follows closely upon Wittgenstein's final explicit remark on Shakespeare. It is not difficult to imagine Wittgenstein writing this with Hamlet, or with something close to Hamlet, in mind:

Look at human beings: one is poison to the other. A mother to her son, and vice versa, etc. But the mother is blind and so is her son. Perhaps they have guilty consciences, but what good does that do them? The child is wicked, but nobody teaches it to be any different and its parents spoil it with their stupid affection; and how are they supposed to understand this and how is their child supposed to understand it? It's as though they were all wicked and all innocent. (VB 1998, p. 98e)

"All wicked and all innocent": unlike the earlier image from the Investigations of one person being an enigma to another, this is a vision of the human condition as both noxious and incoherent. As before, all parties are innocent; but this time there is chaos, and the chaos is of their own making.

It is some such tragic expression of skepticism, a skepticism untamable by the methods of grammatical investigation, that Wittgenstein has in mind when he declares: "The reason I cannot understand Shakespeare is that I want to find symmetry in all this asymmetry" (VB 1998, p. 98a). It is not atypical to read Wittgenstein's appeal to Shakespeare's "asymmetry" as referring to the "sprawling” nature of Shakespeare's plots and subplots (Lewis 2005, p. 249). But beyond noting that this is at most a difference of degree, not of kind, from the fictional writing of such heroes to Wittgenstein as Tolstoy and Dickens, one must ask whether his apparent fastidiousness with regard to formal design doesn't betoken in this case (as it does in others) a wish to repudiate what the unbridled unfolding of events, of turns of mind that lead to turns of fate, itself betokens. And that would be, in Shakespeare's tragedies and tragicomedies, something 
Cavell means by the truth of skepticism: that humans naturally desire, not only an end to the nonsense and to the bumps that the understanding gets by running its head up against the limits of language (PI 1958, §119), but an end to the consequences of speaking (the consequences of expression, the consequences of acknowledging others) altogether. What Wittgenstein covers his ears to may be just this silence, this nothing, that the Shakespearean tragic hero craves. But if it is, then what is revealed in Wittgenstein's dislike for the "creator of language" who "could permit himself anything, so to speak" (VB 1998, p. 98b) is the anxiety or fear that (as in King Lear) something will come of this nothing. ${ }^{11}$

\section{Bibliography}

Cavell, Stanley (1969): "The Avoidance of Love: A Reading of King Lear." In: Stanley Cavell: Must We Mean What We Say? A Book of Essays. Cambridge: Cambridge University Press, p. 267-353.

Cavell, Stanley (1979): “Between Acknowledgment and Avoidance." In: Stanley Cavell: The Claim of Reason: Wittgenstein, Skepticism, Morality, and Tragedy. Oxford: Oxford University Press, p. 329-496.

Cavell, Stanley (1987a): "Othello and the Stake of the Other." In: Stanley Cavell: Disowning Knowledge: In Six Plays of Shakespeare. Cambridge: Cambridge University Press, p. $125-142$.

Cavell, Stanley (1987b): "Recounting Gains, Showing Losses: Reading The Winter's Tale." In: Stanley Cavell: Disowning Knowledge: In Six Plays of Shakespeare. Cambridge: Cambridge University Press, p. 193-221.

Day, William (2010): "Wanting to Say Something: Aspect-Blindness and Language." In: William Day/Victor J. Krebs (Eds): Seeing Wittgenstein Anew. Cambridge: Cambridge University Press, p. 204-224.

Huemer, Wolfgang (2012): “Misreadings: Steiner and Lewis on Wittgenstein and Shakespeare.” In: Philosophy and Literature 36, p. 229-237.

Hughes, Peter (1988): "Painting the Ghost: Wittgenstein, Shakespeare, and Textual Representation." In: New Literary History 19, Wittgenstein and Literary Theory, p. 371-84. Leavis, F. R. (1984): “Memories of Wittgenstein.” In: Rush Rhees (Ed.): Recollections of Wittgenstein. Oxford, New York: Oxford University Press.

Lewis, Peter B. (2005): "Wittgenstein, Tolstoy, and Shakespeare." In: Philosophy and Literature 29 , p. 241-255.

Monk, Ray (1990): Ludwig Wittgenstein: The Duty of Genius. New York: Free Press.

11 This essay began in Budapest in 2004, at a conference organized by Géza Kállay titled "Shakespeare and Philosophy in a Multicultural World." I wish to express my thanks to the participants at that delightful conference, and in particular to Stanley Cavell for his encouragement, and to Géza Kállay for his skepticism.
Pugh, Jonathan (2012): "Wittgenstein, Shakespeare, and Metaphysical Wit." In: Philosophy and Literature 36, p. 238-248.

Rhees, Rush (Ed.) (1984): Recollections of Wittgenstein. Oxford, New York: Oxford University Press.

Shakespeare, William (1876): "Richard II". In: The Works of Shakespeare, Complete and Unabridged. Vol. 6. A. J. Valpy (Ed.). Philadelphia: Gebbie \& Barrie.

Steiner, George (1996): “A Reading against Shakespeare." In: George Steiner: No Passion Spent: Essays 1978-1995. New Haven, London: Yale University Press, p. 108-128. 